DOI: 10.34015/2523-4552.2020.3.17

УДК 340.155

Махаринець М. $\epsilon$., аспірант кафедри історії держави та права Національної академії внутрішніх справ

ORCID: 0000-0003-1478-1306

\title{
СУБ'ЄКТИ ПРАВОВОГО РЕГУЛЮВАННЯ ЗЕМЕЛЬНИХ ВІДНОСИН НА ВОЛИНІ У 20-30-Х РОКАХ ХХ СТОЛІТТЯ
}

У статті досліджується механізм взаємодії суб'єктів реалізації земельної реформи, що проводилась на Волині у 20-30-х роках XX ст. Мета статті - встановити розподіл основних функцій та повноважень суб'єктів правового регулювання земельних відносин. Наукова новизна публікації полягає у дослідженні особливостей організації взаємодії суб'єктів правового регулювання земельних відносин, що проводили земельну реформу на Волині у міжвоєнний період.

Ключові слова: сільське господарство; органи державної влади; приватна власність на землю; земельна ділянка.

В статье исследуется механизм взаимодействия субъектов реализации земельной реформы, которая проводилась на Волыни в 20-30-х годах XX в. Цель статьи - установить основные функций и полномочия субъектов правового регулирования земельных отношений. Научная новизна публикации заключается в исследовании особенностей организации взаимодействия субъектов правового регулирования земельных отношений, которые проводили земельную реформу на Волыни в изучаемый период.

Ключевые слова: сельское хозяйство; органы государственной власти; частная собственность на землю; земельный участок.

Постановка проблеми. Творячи сучасне земельне право, українська держава та її суб'єкти законодавчої ініціативи мають брати до уваги не тільки попередню базу та специфічні риси характеру правосвідомості громадян, які сформувалися історично, але й світовий досвід реформування аграрної галузі. Правове регулювання включає в себе заходи не лише законодавчого, але й виконавчого та контролюючого характеру, що здійснюється державою через органи державної влади. Від вдалого вибору методів регулювання зале- жить ефективність реалізації реформи. Вивчення особливостей організації взаємодії суб'єктів правового регулювання земельних відносин польської держави, що проводили земельну реформу на Волині у міжвоєнний період дозволить визначити більш ефективні норми правового регулювання земельних відносин на сучасному етапі.

Постановка завдання. Встановити розподіл основних функцій та повноважень суб'єктів правового регулювання земельних відносин, їх мету та завдання в ході реалізації 
польської аграрної реформи, яка була запроваджена на Волині у 20-30-х роках XX ст.

Аналіз останніх досліджень і публікацій. Питанням, пов'язаним 3 функціями та повноваженнями суб'єктів правового регулювання земельних відносин, що проводили земельну реформу на Волині у міжвоєнний період, присвячені наукові дослідження таких вітчизняних та польських вчених, як Л. Алексієвець, І. Бойка, В. Виздрика, Ю. Бурдіна, Б. Гудь, Л. Зашкільняка, М. Лапи, В. Менджецького, М. Мещанковського, В. Мусяла та ін.

Виклад основного матеріалу. Аграрна реформа розглядалася у відновленій Польській державі як одна 3 ключових і першочергових. Ї̈̈ причини знаходились у соціальноекономічній та політичній площині. Більшість населення країни проживало в селах і при цьому залишалось малоземельним, в той час, як земля концентрувалася у великих поміщицьких маєтках. Такий розподіл земельної власності неминуче вів до соціальної напруги в суспільстві, що на фоні сусідства з Радянською Росією, була вкрай небезпечною [1, с. 57].

Метою реформи польський уряд декларував за допомогою кардинальної перебудови економічного базису, передусім унаслідок правового регулювання нормами земельного права, створення на основі приватної власності різного типу і розміру селянських господарств, які б були економічно рентабельні і розвивалися на засадах ринкової економіки.

10 липня 1919 p. ухваливши проект «Основи земельної реформи», польський Законодавчий Сейм визначив основу реформи. Цей нормативно-правовий акт запланував що- річний примусовий викуп польською державою частини землі в господарствах, які перевищували встановлену норму: 60 га у промислових та приміських районах, 180 га у сільськогосподарських, 400 га у східних воєводствах(зокрема і на Волині) та Пруссії. Викуплені державою земельні наділи, поділялись на окремі ділянки (парцели) для створення нових селянських господарств.

Цей земельний законопроект, який ініціювали ліві партії, викликав серйозний опір правих сил польського сейму і був прийнятий з перевагою лише в один голос. Меншість вважала його порушенням засадничого права приватної власності. Окрім того, вказували противники змін, у руках поміщиків немає так багато землі, щоб реформа могла забезпечити всіх малоземельних і безземельних селян. Натомість поміщицьке господарство було на той час головним постачальником продовольчої продукції як у середині держави, так і на експорт. Зруйнувавши його, Польща, на думку правих сил, наражається на економічні проблеми. Якщо говорити про українські землі, то тут аргумент правих сил полягав у тому, що така земельна реформа може послабити «стан посідання» та економічну перевагу поляків на «східних кресах». Однак, економісти, пов'язані з ініціаторами реформи, стверджували, що вартість продукції з 1 га $\epsilon$ вищою в інтенсивному селянському господарстві, ніж у більшості екстенсивних поміщицьких маєтках. Зріст заможності у селі, що мав стати наслідком земельної реформи, мав вплинути на збільшення споживання, а це в свою мало викликати розвиток промисловості та зростання інвестиційної активності [2, s. 266]. 
15 липня 1920 р. під час більшовицької інтервенції, польський Сейм ухвалив Закон про виконання земельної реформи. Цей закон передбачав парцеляцію маєтків, які мали більші розміри за встановлений максимум та відшкодування власникам 50\% ринкової вартості землі [3, с. 92]. У вступі стверджувалося, що земельний устрій Польщі передусім повинен опиратися на сильних, здорових і здатних до ефективного виробництва селянських господарствах, що ґрунтуються на основі приватної власності різного типу і розміру.

Після прийняття Конституції 1921 р., земельні закони 1919 та 1920 рр., що передбачали примусову парцеляцію та викуп землі за 50\% ï ринкової вартості, суперечили суті конституційно гарантованому праву приватної власності. Це призвело до фактичної зупинки реалізації земельної реформи. За активної підтримки прем'єр-міністра В. Грабського 28 грудня 1925 р., Сеймом був схвалений новий земельний закон «Про виконання земельної реформи». Викуп позанормованої землі мав проходити за ринковою ціною в залежності від регіону. Передбачалося державна допомога для покупців землі у вигляді кредитів. Власник землі самостійно визначав, яка частина його майна має бути парцельована, а яка збережена ним, до встановленої законом норми [3, с. 93].

Реалізацією земельної реформи займалися два міністерства - земельної реформи і сільського господарства. Перед міністерством земельних реформ було поставлене завдання провести структурну перебудову галузі, перетворюючи нерентабельні, натуральні селянські господарст- ва на самоокупні, економічно ефективні господарства. До завдань міністерств і підлеглих їм інституцій належали: парцеляція, комасація (об'єднання) земель, врегулювання сервітутів та фінансування реформи [4, s. 120]. Головним наслідком парцеляції мала бути ліквідація малоземелля і господарств, земельні ділянки яких розкидані у різних місцях. Для досягнення цієї мети передбачалися парцеляція теренів, які називалися «запасом землі» і складалася 3 державних земель, маєтків «мертвої руки», церковної власності земель державних установ. Законодавці застерігали, що у випадку невиконання плану його належить скоригувати в наступному році. Парцеляційний план, який визначав площу землі, призначеної до розпарцелювання, в окремих повітах встановлювала Рада Міністрів на запит міністра сільського господарства та аграрних реформ.

Земельний закон «Про виконання земельної реформи», прийнятий у 1925 р., мав доволі загальний характер і потребував доопрацювання - необхідно було розв'язати низку правових питань, які стосувались комасації, врегулювання сервітутів та інше. Міністерство реформ на чолі 3 В.Станєвичем протягом 19261930 pp. розробило низку проектів постанов, більшість з яких було видано у вигляді указів (декретів). У зв'язку з прийняттям нових законодавчих актів у земельному законодавстві з'явилась потреба в систематизації та доповненні існуючих норм.

У 1927 р. було створено Комісію по впорядкуванню аграрного законодавства. Завданням аграрної Комісії було опрацювання і впорядкування правових норм 3 аграрних 
питань. В окремих районах Польщі були створені комісії, перед якими було поставлено завдання впорядкувати місцеве законодавства. Метою комісії, що була створена у Волинському воєводстві була систематизація нормативно-правових актів східних земель щодо земельних питань, де особливо вирізнялися питання військового осадництва. Загалом комісії покращили функціонування міністерства реформ в сфері кодифікаційної діяльності - їх починання призвели до опрацювання і внесення на розгляд Ради Міністрів низки проектів законів [4, s. 125-126].

У 1927 р. як дорадчий орган була створена Консультативна земельна комісія, яку очолив Ю. Понятовський. Вона надавала висновки щодо проектів нормативних актів стосовно розвитку лісів, що знаходились не у державній власності, встановлення принципів оцінки землі, що примусово викуплялася в межах земельної реформи, змін в законі про об'єднання грунтів, регулювання торгівлі землею і обмеження поділу земельних ділянок.

Серед різного роду комісій, особливу увагу слід звернути на Раду по покращенню сільськогосподарської системи, що була створена в тому ж році. Ради по покращенню сільськогосподарської системи, були створені як консультативно-дорадчі органи та обговорювали плани, звіти 3 питань діяльності земельних установ, складали висновки щодо проектів законів та розпоряджень, підготовлених міністерством, розглядали плани виконання земельної реформи. При міністерстві реформ було створено також Головну раду, яку очолював міністр земельних реформ, а у кожному воєводстві - створено
Раду воєводства, що очолював воєвода [4, s. 127].

Керівництво та нагляд за належним виконанням аграрної реформи належали до завдань Головного земельного управління. У питаннях, пов'язаних із сільськогосподарським виробництвом, Головне земельне управління діяло у співпраці з міністерством сільського господарства та державного майна. Також була створена Головна Земельна комісія. Виконавчі функції у справах земельної реформи, якою опікувалось Головне земельне управління, виконували Окружні земельні управління. Низовими ланками були повітові земельні управління та гмінні земельні комісії, які відповідали за проведення реформи на своїх територіях [5, s. 461]. Викупом земельних ділянок у власників займалися повітові і окружні адміністративні установи [6, s.32]. Через ці ж державні органи селяни могли купувати землю під час парцеляції. На Волині у 1934 р. був створений орган, що відповідала за реалізацію аграрної реформи Волинська сільськогосподарська палата.

Поруч з державною парцеляцією відбувалась і приватна, ініціаторами котрої виступали в першу чергу землевласники, що потребували коштів для відбудови господарств після Першої світової війни. Приватну парцеляцію проводили також парцеляційні спілки та банки під контролем державних земельних управлінь. Проведення приватної парцеляції було пов'язано з багатьма проблемами, які виникали з браку врегулювання права власності земельних ділянок, що були набуті. Це ускладнювало діяльність новоутворених господарств, зокрема вони не могли 
претендувати на отримання кредитів. Виникали суперечки між сторонами, що укладали договір, які стосувались передусім ціни на землю або браку зацікавленості зі сторони власників в завершенні процесу парцеляції. Причиною цього був той факт, що взята за землю оплата тільки частково покривала борги парцельованого господарства, які мав власник. Тому набагато вигідніше було купувати ділянки землі з державного фонду, але таких було мало.

Право на проведення парцеляції мав і Державний земельний банк, який розпочав парцеляції з 1924 р. Його діяльність полягала в накопиченні землі, створеної шляхом придбання земельних маєтків [7, с. 7475]. До 1926 р. парцеляція, яку проводив банк полягала в основному в продажі запасів землі з попередніх років. У наступний період аграрна діяльність банку значно пожвавилась - було встановлено процедуру опрацювання парцеляції, окреслено засади державної кредитної допомоги для нових власників ділянок, засновано фонд оплати та кредиту. Незважаючи на це, частка банку в загальному парцеляційному процесі була пропорційно мала. В 19261930 рр. це близько 39,3 тис. га, що в порівнянні з іншими типами парцеляції, становило 4\% [8, s. 63].

У 1926-1930 рр. парцеляційні плани були виконані. Пік парцеляційного руху припадає на 19261928 рр. Надалі світова економічна криза загальмувала парцеляційний процес, який відновився лише 3 1936 р. Така динаміка повністю відповідала урядовій концепції аграрних перетворень, де засадничою основою визначалась добровільність, а найважливішим регулятором ринку виступала кон'юктура. Найінтенсивніший парцеляційний рух розвинувся саме у східних воєводствах. Протягом 1921-1938 рр. на Волині було розпарцельовано 335889 га землі.

Суттєвою проблемою аграрного сектору Польщі міжвоєнного періоду було те, що земельна власність одного господаря часто була розпорошена на декілька ділянок. Це було серйозною перепоною для інтенсифікації сільськогосподарського виробництва. У ході комасації (об'єднанні земель) кожен селянин одержував взамін за належні йому парцели скомасовану частину грунту тієї самої вартості. Якщо вартість грунтів перед перетворенням і після них була різною, польський уряд компенсував різницю власнику. Об'єднання земель відбувалося на добровільній основі. Селянам, що прагнули об'єднати свої земельні наділи, необхідно було подати відповідне прохання до повітового земельного уряду. Ці установи готували плани комасації та складали перелік учасників, які затверджувалися Окружною земельною комісією. До плану комасації входила карта земель, планування шляхів сполучення і під'їздів, відведення місць під громадські споруди, об'єкти господарського призначення (кар'єри, копальні) тощо. Це мало позитивно вплинути на загальний благоустрій сіл. Процес комасації був платним - фінансування відбувалося як з боку селянина, так і влади. Селяни здійснювали оплату землемірних робіт залежно від площі землі. Якщо селянин не мав коштів на проведення об'єднання земельних ділянок, то Державний сільськогосподарський банк міг надати кредит. Також із Оборотного фонду аграрної реформи 
виділялися кошти на оплату вимірювального та контролюючого персоналу [9, с. 128]. У 1928-1937 pp. комасація на Волині охопило близько 750000 га в 690 селах, а в 1938 р. комасаційні роботи тривали ще в 230 селах. Однак об'єднання земельних ділянок вимагало ще 900 сіл та 740000 га [10, s. 53].

Загалом, комасація на Волині проходила повільно. Дослідники серед основних причин, вказують на наявність анклавів державних земель, що врізались у селянські землі і це значно ускладнювало процес об'єднання грунтів. Цей процес утруднювався відсутністю документів на земельні ділянки у селян та браком кваліфікованого технічного персоналу. В цілому у Волинському воєводстві реорганізацією земельного устрою займались 199 особи, з яких із відповідною кваліфікацією було лише 63 фахівці, 35 практикантів та 96 землевпорядників без фахової підготовки [11, арк. 8]. Волинська адміністрація складну кадрову ситуацію у воєводстві порівняно з іншими регіонами Польщі пояснювала низькою оплатою праці персоналу при доволі складних виробничих та побутових умовах [9, с. 130].

Ще одним напрямком реформи була ліквідація сервітутів, започаткована ще в 1920 р., але почала широко проводитись тільки з 1926 р. Це регулювалося розпорядженням Президента від лютого 1927 р. Як і в випадку парцеляцій, ліквідація сервітутів могла відбуватися як приватна домовленість селян з власником землі так і примусово. В 1926-1930 pp. сервітутів ліквідовано в 153,5 тис. господарств, які отримали за це еквівалент землі 426,6 тис. га. Усього за період 1921-1939 pp. сервітути у
Волинському воєводстві були ліквідовані на площі 77,992 га. Основна форма сервітутів становили пасовища у поліській зоні. У середньому по воєводству із цієї площі великі власники втратили $1 / 4$ частину землі (близько 20 тис.га).

31927 р., коли було видане розпорядження президента Польщі про ліквідацію сервітутів, у деяких східних воєводствах, в тому числі й у Волинському, акція відбувалася примусово, але це дозволило проведення комасації на теренах, обтяжених сервітутами. На думку дослідників, розпорядження 1927 р., яке санкціонувало примусову ліквідацію сервітутів, завдало шкоди інтересам малоземельних селян, для яких сервітути часто були джерелом безкоштовного хмизу для палива. Селяни противилися ліквідації сервітутів, оскільки часто взамін вони отримували невеликі й малоцінні наділи землі [4, s. 135]. Процес ліквідації сервітутів надав можливість великим господарствам зробити своє виробництво більш ефективним. У ході ліквідації сервітутів зменшувались не тільки приватні земельні володіння, але й державні, у першу чергу це стосувалось державних лісів.

Регулювання правовідносин у сільському господарстві потребувало від польської держави значних коштів. Тому законодавці передбачили фінансову допомогу для малозабезпечених господарств. Джерелами фінансування реформи були державний бюджет, фонд аграрної реформи, надходження від рент, а також погашення кредитів 3 фондів допомоги. Основним джерелом фінансування земельної реформи був бюджет міністерства реформи. У 19261931 рр. $з$ цією метою було видано 
351705 млн. злотих. Державний земельний банк надавав довготривалі кредити на викуп землі. Одним 3 елементів фінансування була емісія державних облігацій. Кредити Державного земельного банку поширювалися на великі і середні господарства та робітників, які працювали в сільському господарстві. Їм надавалися кредити на закупку землі з парцеляції та на комасацію земельних ділянок і меліорацію [4, s. 137-138].

Висновки. В умовах аграрних трансформацій, що відбувалися на Волині у 20-30-х роках XX ст., у результаті проведення польським урядом земельної реформи ключове значення набуває діяльність суб'єктів правового регулювання земельних відносин, їх взаємодія та ефективність. Адже правове регулювання включає в себе заходи не лише законодавчого, але й виконавчого та контролюючого характеру, що здійснюються державою через органи державної влади. В ході проведення польським урядом земельної реформи ключове значення набула діяльність суб'єктів правового регулювання земельних відносин, їх взає- модія та ефективність. Була створена правова та інституційна база, сформована система державного управління земельними ресурсами, суб'єкти регулювання земельних правовідносин діяли в межах своїх повноважень. Аграрна реформа та політика польського уряду 3 цього питання мала певні здобутки, але вона не стала успішною. Мету, яку ставив перед собою польський уряд - створення на основі приватної власності різного типу селянських господарств, які б були економічно рентабельні та стали домінуючими в аграрному секторі - виконати не вдалось. Земельна реформа не змогла розв'язати головної проблеми волинського селянства - земельного дефіциту в регіоні зокрема, так як і в цілому по країні. Недосконалість нормативно-правової бази та методів правового регулювання, недостатня фінансова підтримка з боку польської держави, відірваність аграрних перетворень від реформування в інших галузях економічної системи і в першу чергу промисловості, світова економічна криза не дозволили отримати ефективний результат.

\section{Список використаних джерел}

1. Романишин Н. Причини та наслідки аграрної реформи у міжвоєнній Польщі. Україна - Польща: стратегічне партнерство в системі геополітичних координат: зб. наукових праць II міжнар. наук.-практ. конф., Київ, 14-15 травня 2020 р. Київ : «Міленіум», 2020. С. 57-59.

2. Jezerski A., Leszczynska C. (1999). Historia gospodarcza Polski. Warszawa : Key Text. $560 \mathrm{~s}$.

3. Романишин Н. Земельна реформа в Другій Речі Посполитій: шляхи реалізації та наслідки. «Проблеми гуманітарних наук». Серія: Історія., Вип. 3 (45). Дрогобич. 2020. C. 87-100. DOI: 10.24919/2312-2595.3/45.203983.

4. Małgorzata Łapa. Problemy przebudowy strukturalnej rolnictwa polskiego w latach 1926-1930. Program agrarny Witolda Staniewicza. Acta universitatis Lodziensis. Folia historica 66, 1999. S. 119-140.

5. Ustawa z dn. 6 lipca 1920 r. o organizacji urzędów ziemskich. (1920). Dziennik Ustaw Rzeczypospolitej Polskiej, 70 (461), 1222-1229. 
6. Monika Cepil, Tomasz Figlus. Parcelacja wsi w okresie międzywojennym i jej reperkusje osadnicze na przykładzie folwarków Orzeszków, Wielenin i Zieleń. Biuletyn uniejowski. Tom 7. 2018. S. 29-45.

7. Шкуратенко О. В., Єрмак В. В. Польська аграрна реформа на західноукраїнських землях у 20-х рр. XX ст. Україна - Польща: стратегічне партнерство в системі геополітичних координат: зб. наукових праць II міжнародної наук.-практ. Конференції. Київ, 14-15 травня 2020 р. Київ : «Міленіум», 2020. С. 74-77.

8. Nowak M. Państwowy Bank Rolny w Drugiej Rzeczypospolitej. Kraków: Secesja, 1988. $122 \mathrm{~s}$.

9. Никитюк Т. Л., Баула О. В. Господарський досвід проведення аграрних перетворень (зцілення земель) у Волинському регіоні у 1919-1939 роках. Економічні науки. Серія «Економічна теорія та економічна історія». Збірник наукових праць. Луцький НТУ. Випуск 11 (44). Луцьк, 2014. С.122-132.

10. Mędrzecki W. Wojewódzstwo Wołyńskie 1921-1939. Elementy przemien cywilizacyjnych, społecznych i politycznych. Wroclaw-Warszawa-Kraków-GdańskŁódz, 1988. 202 s.

11. Державний Архів Волинської Області. Фонд 46. Оп. 4. Спр. 380. Ар.82.

\section{References}

Romanishin, N. (2020). Prichini ta naslidki agrarnoyi reformi u mizhvoyennij Polshi. Ukrayina - Polsha: strategichne partnerstvo v sistemi geopolitichnih koordinat: Zb. naukovih prac II mizhnar. nauk.-prakt. konf., Kiyiv, 14 -15 travnya 2020 r. Kiyiv: «Milenium», 57-59 [in Ukranian].

Jezerski A., Leszczynska C. (1999). Historia gospodarcza Polski. Warszawa: Key Text.

Romanishin, N. (2020). Zemelna reforma v Drugij Rechi Pospolitij: shlyahi realizaciyi ta naslidki. «Problemi gumanitarnih nauk». Seriya: Istoriya., Vip. 3 (45). Drogobich, 87-100. DOI: 10.24919/2312-2595.3/45.203983 [in Ukranian].

Malgorzata, Lapa. (1999). Problemy przebudowy strukturalnej rolnictwa polskiego w latach 1926-1930. Program agrarny Witolda Staniewicza. Acta universitatis Lodziensis. Folia historica 66, 119-140.

Monika, Cepil, Tomasz, Figlus. (2018). Parcelacja wsi w okresie miedzywojennym i jej reperkusje osadnicze na przykladzie folwarkow Orzeszkow, Wielenin i Zielen. Biuletyn uniejowski, 7, 29-45.

Shkuratenko, O. V., Yermak, V. V. Polska agrarna reforma na zahidnoukrayinskih zemlyah u 20-h rr. HH st. Ukrayina - Polsha: strategichne partnerstvo v sistemi geopolitichnih koordinat: zb. naukovih prac II mizhnarodnoyi nauk.-prakt. Konferenciyi. Kiyiv, 14-15 travnya 2020 r. Kiyiv: «Milenium», 2020, 74-77 [in Ukranian].

Nowak, M. (1988). Panstwowy Bank Rolny w Drugiej Rzeczypospolitej. Krakow: Secesja.

Nikityuk T. L., Baula O. V. (2014). Gospodarskij dosvid provedennya agrarnih peretvoren (zcilennya zemel) u Volinskomu regioni u 1919-1939 rokah. Ekonomichni nauki. Seriya "Ekonomichna teoriya ta ekonomichna istoriya». Zbirnik naukovih prac. Luckij NTU. Vipusk 11 (44). Luck, 122-132 [in Ukranian].

Mędrzecki, W. (1988). Wojewódzstwo Wołyńskie 1921-1939. Elementy przemien cywilizacyjnych, społecznych i politycznych. Wroclaw-Warszawa-Kraków-Gdańsk-Łódz. 
M. Makharynets, Postgraduate Student of the Department of History of State and Law of the National Academy of Internal Affairs

ORCID: 0000-0003-1478-1306

\section{Subjects of legal regulation of land relations in Volyn in the 20 - 30 years of $X X$ century}

In the provisions of the legal article is researched a mechanism of correlation of subjects of realisation of law reform, which was conducted in Volyn in the 20-30 years of XX century by Poland.

Aim of the article is to establish main functions and authorities of subjects of the legal regulation of land relations. Also their goals and tasks on the course of realisation of Polish agrarian reform in Volyn in the 20-30 years of XX century.

Scientific novelty of the article is research on peculiarities of organisation of correlation between subjects of legal regulation of land relations, that were leading land reform in the interwar period in Volyn.

Conclusions. On the conditions of the agrarian transformation that occurred in Volyn in the 20-30 years of XX century in the course of conducting an agrarian reform by Polish government, activity of the subjects of legal regulations, their correlation and effectiveness had begun to be the key element. Legal and institutional base was established, formed a system of State government of land resources, subjects of the regulation were performing their duties on the frames of their authorities. But, non perfection of legal basis as well as of the methods of legal regulations, not enough financial aid from Polish state, separability of agrarian transformations from other reforms of the economical system, on the first place from industries, world economic crisis, all these factors didn't allow to achieve the desired result.

Keywords: agriculture; body of state authority; private land property; land plot. 